Prepared in cooperation with the New York State Department of Environmental Conservation

\title{
Flood-Inundation Maps for the Schoharie Creek at Prattsville, New York, 2014
}

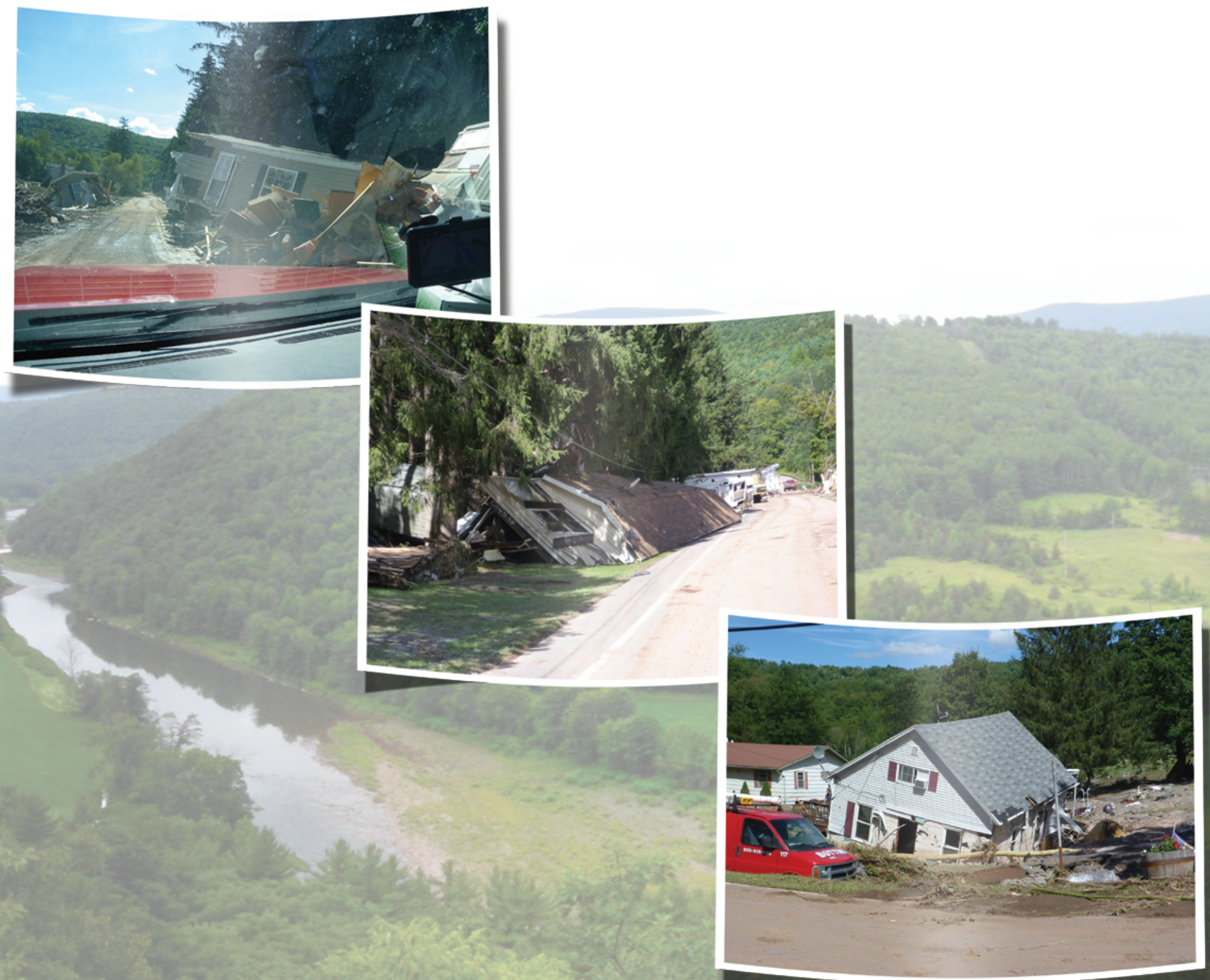

Scientific Investigations Report 2015-5190

U.S. Department of the Interior

U.S. Geological Survey 
Cover. Background photograph: Schoharie Valley from the top of Pratt Rock, July 9, 2015.

Other photographs: Damage in Prattsville caused by the flood of August 2011, following Tropical Storm Irene. Photographs by Paul Guse, U.S. Geological Survey. 


\title{
Flood-Inundation Maps for the Schoharie Creek at Prattsville, New York, 2014
}

\author{
By Elizabeth A. Nystrom
}

Prepared in cooperation with the

New York State Department of Environmental Conservation

Scientific Investigations Report 2015-5190 


\title{
U.S. Department of the Interior SALLY JEWELL, Secretary
}

\section{U.S. Geological Survey Suzette M. Kimball, Director}

\author{
U.S. Geological Survey, Reston, Virginia: 2016
}

For more information on the USGS - the Federal source for science about the Earth, its natural and living resources, natural hazards, and the environment-visit http://www.usgs.gov/ or call 1-888-ASK-USGS.

For an overview of USGS information products, including maps, imagery, and publications, visit http://www.usgs.gov/pubprod/.

Any use of trade, firm, or product names is for descriptive purposes only and does not imply endorsement by the U.S. Government.

Although this information product, for the most part, is in the public domain, it also may contain copyrighted materials as noted in the text. Permission to reproduce copyrighted items must be secured from the copyright owner.

Suggested citation:

Nystrom, E.A., 2016, Flood-inundation maps for the Schoharie Creek at Prattsville, New York, 2014: U.S. Geological Survey Scientific Investigations Report 2015-5190, 12 p., 17 sheets, http://dx.doi.org/10.3133/sir20155190.

ISSN 2328-0328 (online) 


\section{Acknowledgments}

The author wishes to thank the New York City Department of Environmental Protection, the New York Power Authority, and the New York State Department of Environmental Conservation. These agencies have helped support the operation and maintenance of the Schoharie Creek at Prattsville streamgage. Special thanks are given to the National Weather Service for continued support of the U.S. Geological Survey flood-inundation mapping initiative. 



\section{Contents}

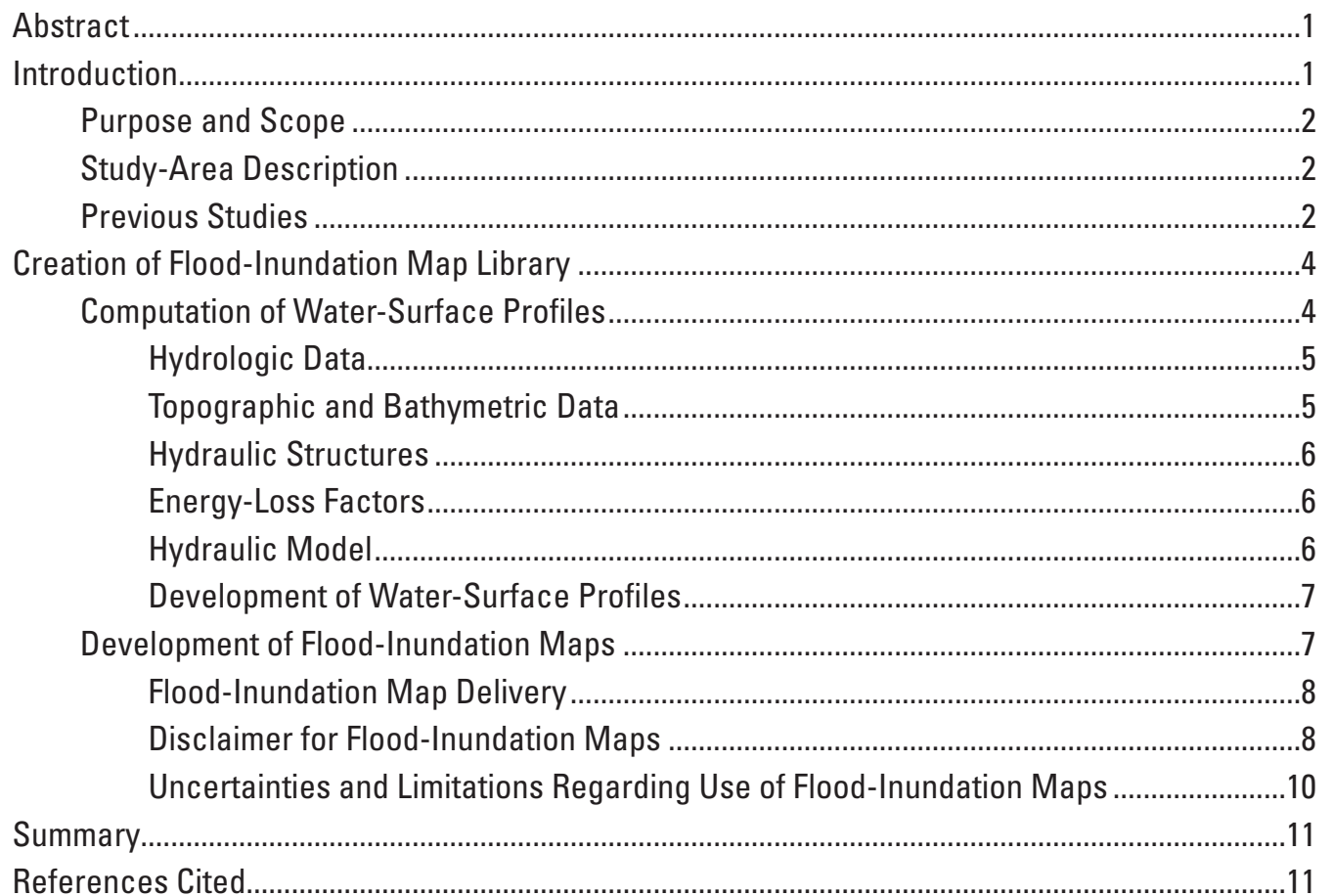

\section{Sheets}

[Available separately at http://dx.doi.org/10.3133/sir20155190.]

1-17. Flood-inundation maps for Prattsville, New York, referenced to U.S. Geological Survey streamgage 01350000 on the Schoharie Creek

1. Stage of 9 feet and elevation of 1,139.96 feet (North American Vertical Datum of 1988 [NAVD 88])

2. Stage of 10 feet and elevation of $1,140.96$ feet (NAVD 88)

3. Stage of 11 feet and elevation of 1,141.96 feet (NAVD 88)

4. Stage of 12 feet and elevation of 1,142.96 feet (NAVD 88)

5. Stage of 13 feet and elevation of $1,143.96$ feet (NAVD 88)

6. Stage of 14 feet and elevation of 1,144.96 feet (NAVD 88)

7. Stage of 15 feet and elevation of $1,145.96$ feet (NAVD 88)

8. Stage of 16 feet and elevation of 1,146.96 feet (NAVD 88)

9. Stage of 17 feet and elevation of $1,147.96$ feet (NAVD 88)

10. Stage of 18 feet and elevation of $1,148.96$ feet (NAVD 88)

11. Stage of 19 feet and elevation of 1,149.96 feet (NAVD 88)

12. Stage of 20 feet and elevation of 1,150.96 feet (NAVD 88)

13. Stage of 21 feet and elevation of $1,151.96$ feet (NAVD 88)

14. Stage of 22 feet and elevation of $1,152.96$ feet (NAVD 88) 
15. Stage of 23 feet and elevation of 1,153.96 feet (NAVD 88)

16. Stage of 24 feet and elevation of $1,154.96$ feet (NAVD 88)

17. Stage of 25 feet and elevation of $1,155.96$ feet (NAVD 88)

\section{Figures}

1. Map showing location of study reach for the Schoharie Creek at Prattsville, New York, and location of U.S. Geological Survey streamgage 01350000, which is also a National Weather Service forecast site

2. Graph showing observed water-surface elevations and simulated water-surface profile for the flood of August 28, 2011, for Schoharie Creek at Prattsville, New York .8

3. Flood-inundation map for the Schoharie Creek at Prattsville, New York, corresponding to a stage of 25.00 feet at the U.S. Geological Survey streamgage (station number 01350000)

\section{Tables}

1. U.S. Geological Survey streamgage and miscellaneous site information for study basin, Schoharie Creek at Prattsville, New York

2. Annual exceedance probability peak-discharge estimates for the Schoharie Creek at Prattsville, New York, streamgage, station number 01350000

3. Estimated discharges for corresponding stages and water-surface elevations at selected locations, used in the hydraulic model of the Schoharie Creek at Prattsville, New York

4. Calibration of model to observed water-surface elevations at U.S. Geological Survey streamgage on Schoharie Creek at Prattsville, New York (station number 01350000) 


\section{Conversion Factors}

Inch/Pound to International System of Units

\begin{tabular}{lll}
\hline \multicolumn{1}{c}{ Multiply } & \multicolumn{1}{c}{ By } & \multicolumn{1}{c}{ To obtain } \\
\hline foot $(\mathrm{ft})$ & 0.3048 & meter $(\mathrm{m})$ \\
mile $(\mathrm{mi})$ & 1.609 & kilometer $(\mathrm{km})$ \\
square mile $\left(\mathrm{mi}^{2}\right)$ & 2.590 & square kilometer $\left(\mathrm{km}^{2}\right)$ \\
cubic foot per second $\left(\mathrm{ft}^{3} / \mathrm{s}\right)$ & 0.02832 & cubic meter per second $\left(\mathrm{m}^{3} / \mathrm{s}\right)$ \\
foot per mile $(\mathrm{ft} / \mathrm{mi})$ & 0.1894 & meter per kilometer $(\mathrm{m} / \mathrm{km})$ \\
\hline
\end{tabular}

\section{Datum}

Vertical coordinate information is referenced to either stage (the height above an arbitrary datum established at a streamgage) or elevation (the height above the North American Vertical Datum of 1988 [NAVD 88]).

Horizontal coordinate information is referenced to the North American Datum of 1983 (NAD 83).

Elevation, as used in this report, refers to distance above the vertical datum.

\section{Abbreviations}

$\begin{array}{ll}\text { AEP } & \text { annual exceedance probability } \\ \text { AHPS } & \text { Advanced Hydrologic Prediction Service } \\ \text { DEM } & \text { digital elevation model } \\ \text { FEMA } & \text { Federal Emergency Management Agency } \\ \text { FIS } & \text { flood insurance study } \\ \text { GIS } & \text { geographic information system } \\ \text { HEC-RAS } & \text { Hydrologic Engineering Center-River Analysis System } \\ \text { lidar } & \text { light detection and ranging } \\ \text { NWIS } & \text { National Water Information System } \\ \text { NWS } & \text { National Weather Service } \\ \text { RTK } & \text { real-time kinematic } \\ \text { USGS } & \text { U.S. Geological Survey }\end{array}$





\title{
Flood-Inundation Maps for the Schoharie Creek at Prattsville, New York, 2014
}

\author{
By Elizabeth A. Nystrom
}

\section{Abstract}

Digital flood-inundation maps for a 2.6-mile reach of the Schoharie Creek at Prattsville, New York, were created by the U.S. Geological Survey (USGS) in cooperation with the New York State Department of Environmental Conservation. The flood-inundation maps, which can be accessed through the USGS Flood Inundation Mapping Science Web site at http://water.usgs.gov/osw/flood_inundation/, depict estimates of the areal extent and depth of flooding corresponding to selected water levels (stages) at the USGS streamgage at Schoharie Creek at Prattsville (station number 01350000). Near-real-time stages at this streamgage may be obtained online from the USGS National Water Information System (http://waterdata.usgs.gov/) or the National Weather Service Advanced Hydrologic Prediction Service (http://water.weather. gov/ahps/), which also forecasts flood hydrographs at this site. National Weather Service-forecasted peak-stage information may be used in conjunction with the maps developed in this study to show predicted areas and depths of flood inundation.

Flood profiles were computed for the stream reach by means of a one-dimensional step-backwater model. The model was calibrated by using the stage-discharge relation (rating 82.0) at the Schoharie Creek at Prattsville streamgage (station 01350000) and high-water marks from the flood of August 28, 2011. The hydraulic model was then used to compute 17 water-surface profiles for flood stages at 1-foot intervals referenced to the streamgage datum and ranging from bankfull to greater than the highest recorded water level at the streamgage. The simulated water-surface profiles were then combined with a geographic information system digital elevation model, derived from light detection and ranging (lidar) data having a 0.61 -foot vertical root-mean squared error and 6.6-foot horizontal resolution, in order to delineate the area flooded at each water level.

These flood-inundation maps, along with near-real-time stage data from USGS streamgages and forecasted stage data from the National Weather Service, can provide emergency management personnel and residents with information that is critical for flood response activities such as evacuations and road closures as well as for postflood recovery efforts.

\section{Introduction}

The Town of Prattsville, New York, is a small community with an estimated population of 700 (U.S. Census Bureau, 2010). The unincorporated village of Prattsville within the Town of Prattsville has experienced numerous severe floods, most notably in 1955, 1996, and 2011. Most flood damages have occurred along the Schoharie Creek and its tributary, Huntersfield Creek, which flow through the village. Flood plains within Prattsville are moderately developed and contain a mix of residential and commercial structures.

Before this study, emergency responders in Prattsville relied on several information sources (all available online) to decide how to best alert the public and mitigate flood damages. One source is the Federal Emergency Management Agency (FEMA) flood insurance study (FIS) for Greene County, N.Y., (Federal Emergency Management Agency, 2008). A second source is the U.S. Geological Survey (USGS) streamgage at Schoharie Creek at Prattsville, from which current (2015; U.S. Geological Survey, 2015a) and historical (since 1902; U.S. Geological Survey, 2015c) water levels and discharges, including annual peak flows, can be obtained. A third source of flood-related information is the National Weather Service (NWS) Advanced Hydrologic Prediction Service (AHPS), which displays the USGS stage data from the Prattsville streamgage and also forecasts stage for the Schoharie Creek at Prattsville (National Weather Service, 2015b).

Although the current stage at a USGS streamgage is particularly useful for residents in the immediate vicinity of a streamgage, it is of limited use to residents farther upstream or downstream because the water-surface elevation is not constant along the entire stream reach. Knowledge of a water level at a streamgage is difficult to translate into depth and areal extent of flooding at points distant from the streamgage. One way to address these information gaps is to produce a library of flood-inundation maps that are referenced to the stages recorded at a USGS streamgage. By referring to the appropriate map, emergency responders can discern the severity of flooding (depth of water and areal extent), identify roads that are or will soon be flooded, and make plans for notification or evacuation of residents upstream and downstream from the streamgage. In addition, 
the capability to visualize the potential extent of flooding can motivate residents to take precautions and heed warnings that they otherwise might disregard. In 2013-14, the USGS, in cooperation with the New York State Department of Environmental Conservation, created a flood-inundation map library for the Schoharie Creek at Prattsville.

\section{Purpose and Scope}

This report describes the development of a series of estimated flood-inundation maps for the Schoharie Creek at Prattsville and identifies where the maps and ancillary data (geographic information system [GIS] flood polygons and depth grids) can be downloaded.

The mapped study reach extends 2.6 miles (mi) from the confluence of Schoharie Creek and the Batavia Kill to approximately $0.5 \mathrm{mi}$ upstream of the Schoharie Reservoir (fig. 1). The maps were produced for flood levels referenced to the stage at the USGS streamgage on the Schoharie Creek at Prattsville (table 1); the streamgage is located approximately midway through the study reach and just upstream from the bridge on State Route 23. The maps cover a range in stage from 9 to 25 feet ( $\mathrm{ft}$ ), referenced to the streamgage datum. The 9-ft stage is approximately bankfull and is defined by the National Weather Service (2015a) as the action stage or that stage which, when reached by a rising stream, requires the NWS or a partner to take mitigation action in preparation for possible flooding. The 25 -ft stage exceeds the maximum recorded peak flow stage $(24.38 \mathrm{ft}$ on August 28,2011$)$ and the estimated 0.2-percent annual exceedance probability (AEP) flood stage (500-year recurrence interval flood).

Methods used are generally cited from previously published reports. If techniques varied substantially from previously documented methods because of local hydrologic conditions or availability of data, they are described in detail in this report.

\section{Study-Area Description}

The Schoharie Creek is in the Catskill Mountain region of southeastern New York. The headwaters originate in Greene County, and the streamflows generally northward before entering Prattsville. The modeled study reach extends $3.5 \mathrm{mi}$ from the confluence of Schoharie Creek and the Batavia Kill downstream into the upper reach of the Schoharie Reservoir; to avoid substantial backwater from the reservoir, $0.9 \mathrm{mi}$ of the modeled reach ( $0.4 \mathrm{mi}$ of which is within the upper reach of the reservoir) was removed from the downstream extent of the mapped study reach (fig. 1). The mapped study reach is approximately $2.6 \mathrm{mi}$ long and has an average top-ofbank channel width of about $265 \mathrm{ft}$ and an average channel slope of 0.003 ( 16 feet per mile). The drainage area ranges from 227 square miles $\left(\mathrm{mi}^{2}\right)$ downstream of the confluence with the Batavia Kill to $244 \mathrm{mi}^{2}$ at the confluence with Schoharie Reservoir; the drainage area at the Schoharie Creek at Prattsville streamgage is $237 \mathrm{mi}^{2}$. The basin terrain is generally hilly to mountainous. Two minor tributaries to the Schoharie Creek-Huntersfield Creek and Johnson Hollow Brook - join the main stem as it flows through the study reach. About 27 percent of the land contiguous to the mapped study reach is classified as urban or developed, 13 percent as forest, and 22 percent as cropland and grassland; the remaining 38 percent consists of open water and wetlands (Homer and others, 2015). The main channel within the modeled study reach has one major road crossing and two low-head dams; one of the low-head dams falls within the modeled study reach but not the mapped study reach (fig. 1).

\section{Previous Studies}

The current FIS for Prattsville (Federal Emergency Management Agency, 2008) is a county-wide study for Greene County and was completed by PAR Government Systems and the New York State Department of Environmental Conservation in 2004. The FIS provides estimates for the 10-, 2.0-, 1.0-, and 0.2-percent annual exceedance probability (AEP) water-surface profiles and associated flood-plain maps for the Schoharie Creek and several of its tributaries. Hydraulic analyses used a Hydrologic Engineering Center-River Analysis System (HEC-RAS) model based on a digital elevation model (DEM) derived from light detection and ranging (lidar) data for overbank areas and field survey data for channel areas. Estimates of the peak discharges for the 10-, 2.0-, 1.0-, and 0.2-percent AEP floods for the Schoharie Creek at Prattsville streamgage, as listed in table 2, are described by FEMA (2008).

Many other flood-related studies have been conducted in and around the inundation-mapping study area. Lumia and others (2014) documented high-water marks, flood profiles, and event hydrographs for several flood events which occurred during 2011. Wall and others (2014) documented maximum stages and their AEPs at streamgages throughout New York and presented AEPs updated to include data through 2011. Zembrzuski and Evans (1989) and Lumia (1998) documented flood discharge, high-water marks, and flood profiles along the Schoharie Creek for the floods of April 4-5, 1987, and January 19-20, 1996, respectively.

As part of community and stakeholder responses following the flood of August 28, 2011, caused by the remnants of Hurricane Irene, the hydraulic model used in the FEMA FIS was adapted to investigate flood mitigation options (Milone and MacBroom, Inc., 2013; NY Rising Community Reconstruction Program Prattsville Planning Committee, 2014). The State Route 23 bridge over the Schoharie Creek is targeted for potential replacement as part of a scour critical/ flood prone bridge program (New York State Department of Transportation, 2014). The New York State Department of Transportation conducted field surveys of the stream channel for use in a hydraulic model as part of the bridge replacement scoping and planning process. Replacement of the State 


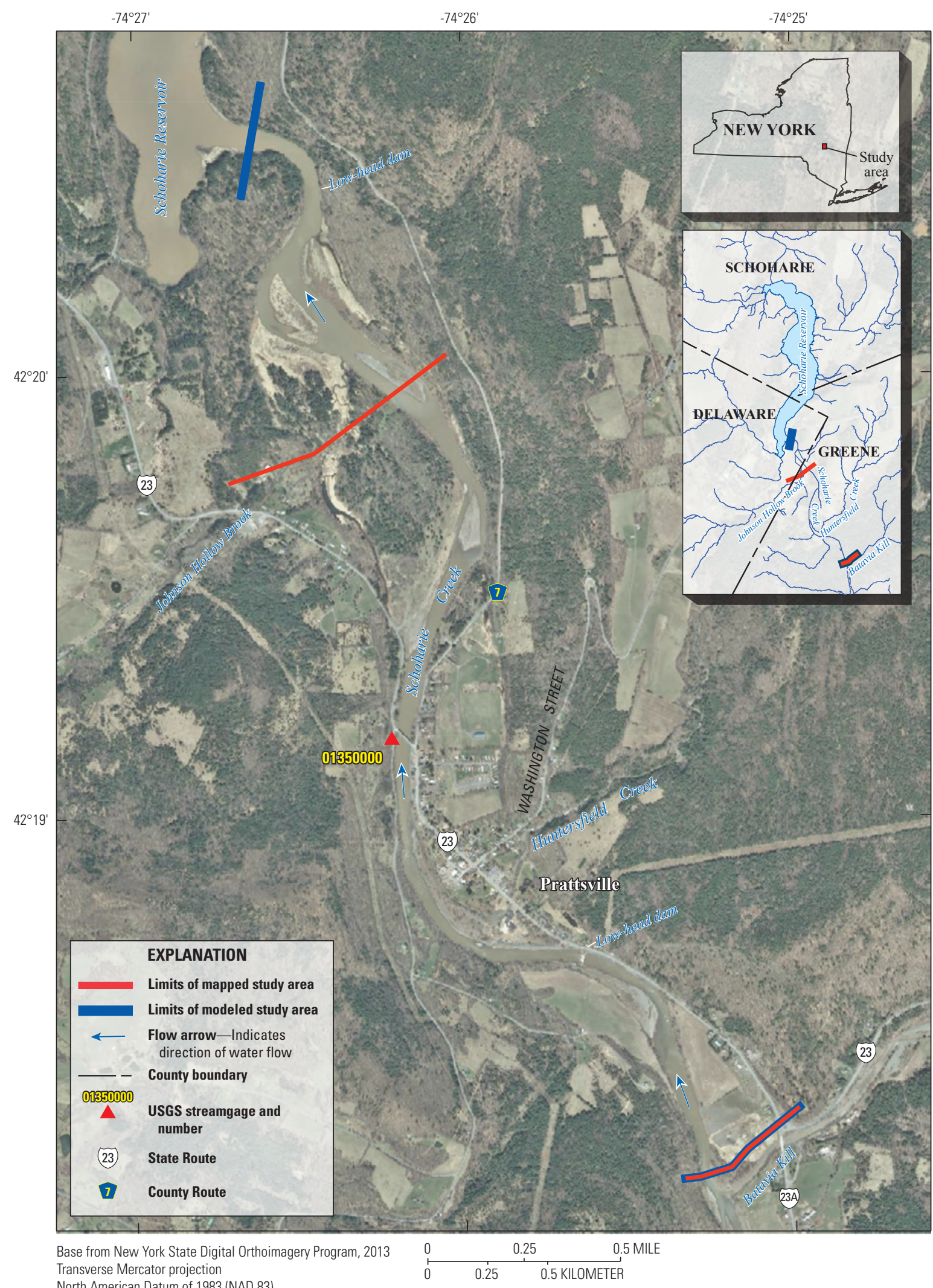

Figure 1. Location of study reach for the Schoharie Creek at Prattsville, New York, and location of U.S. Geological Survey (USGS) streamgage 01350000, which is also a National Weather Service forecast site. 
Table 1. U.S. Geological Survey streamgage and miscellaneous site information for study basin, Schoharie Creek at Prattsville, New York.

[Latitude and longitude are in degrees, minutes, and seconds. $\mathrm{mi}^{2}$, square miles; ft, feet; NAVD 88, North American Vertical Datum of 1988 ; $\mathrm{ft}^{3} / \mathrm{s}$, cubic feet per second; NY, New York]

\begin{tabular}{|c|c|c|c|c|c|c|c|c|c|}
\hline \multirow[b]{2}{*}{ Station name } & \multirow{2}{*}{$\begin{array}{l}\text { Station } \\
\text { number }\end{array}$} & \multirow{2}{*}{$\begin{array}{c}\text { Drainage } \\
\text { area } \\
\left(\mathrm{mi}^{2}\right)\end{array}$} & \multirow[b]{2}{*}{ Latitude } & \multirow[b]{2}{*}{ Longitude } & \multirow[b]{2}{*}{ Period of record } & \multicolumn{4}{|c|}{$\begin{array}{l}\text { Maximum recorded stage at streamgage } \\
\text { and corresponding information }\end{array}$} \\
\hline & & & & & & $\begin{array}{l}\text { Stage } \\
(\mathrm{ft})\end{array}$ & $\begin{array}{l}\text { Elevation } \\
\text { (ft above } \\
\text { NAVD 88) }\end{array}$ & Date & $\begin{array}{l}\text { Discharge } \\
\qquad\left(\mathrm{ft}^{3} / \mathrm{s}\right)\end{array}$ \\
\hline $\begin{array}{l}\text { Schoharie Creek at } \\
\text { Prattsville, NY }\end{array}$ & 01350000 & 237 & $42^{\circ} 19^{\prime} 10^{\prime \prime}$ & $74^{\circ} 26^{\prime} 12^{\prime \prime}$ & $\begin{array}{l}\text { November } 1902 \\
\text { to current year } \\
(2015)^{1}\end{array}$ & 24.38 & $1,155.34$ & August 28, 2011 & 120,000 \\
\hline
\end{tabular}

${ }^{1}$ Period of peak-flow record October 1903 to current year (2015).

Route 23 bridge will likely alter the hydraulic properties of the channel at that location and, therefore, could affect the stage-discharge relation at the Schoharie Creek at Prattsville streamgage and the mapped inundated areas at a given stage. The current study is based on field conditions as of October 2014.

\section{Creation of Flood-Inundation Map Library}

The USGS has standardized the procedures for creating flood-inundation maps for flood-prone communities (U.S. Geological Survey, 2015b) so that the methods and products are similar regardless of which USGS office is responsible for the work. Tasks specific to development of the flood maps for Prattsville were (1) collection of topographic and bathymetric data for selected cross sections and geometric data for structures and bridges along the study reach, (2) compilation of hydrologic data, (3) estimation of energy-loss factors (roughness coefficients) in the stream channel and flood plain and determination of steady-flow data, (4) computation of water-surface profiles using the U.S. Army Corps of Engineers HEC-RAS computer program (U.S. Army Corps of Engineers, Hydrologic Engineering Center, 2010),
(5) production of estimated flood-inundation maps at various stream stages using the U.S. Army Corps of Engineers HECGeoRAS computer program (U.S. Army Corps of Engineers, Hydrologic Engineering Center, 2009) and a GIS, and

(6) preparation of the maps, both as shapefile polygons that depict the areal extent of flood inundation and as depth grids that provide the depth of floodwaters, for display on a USGS flood-inundation mapping application.

\section{Computation of Water-Surface Profiles}

The water-surface profiles used to produce the 17 floodinundation maps in this study were computed by using HEC-RAS, version 4.1.0 (U.S. Army Corps of Engineers, Hydrologic Engineering Center, 2010). HEC-RAS is a one-dimensional step-backwater model for simulation of water-surface profiles with steady-state (gradually varied) or unsteady-state flow computation options. The mapped study reach extends $2.6 \mathrm{mi}$ from the confluence of Schoharie Creek and the Batavia Kill to approximately 0.5 mi upstream of the Schoharie Reservoir. The hydraulic model used to create the maps extends downstream of the mapped study reach to the confluence of Schoharie Creek and Schoharie Reservoir; however, because this area is subject to influence by reservoir levels, it was not mapped.

Table 2. Annual exceedance probability peak-discharge estimates for the Schoharie Creek at Prattsville, New York, streamgage, station number 01350000.

[Data are from Federal Emergency Management Agency (2008) and Wall and others (2014). $\mathrm{ft}^{3} / \mathrm{s}$, cubic feet per second; FEMA, Federal Emergency Management Agency; FIS, flood insurance study; USGS, U.S. Geological Survey; SIR, Scientific Investigations Report]

\begin{tabular}{|c|c|c|c|c|}
\hline \multirow[t]{2}{*}{ Data source } & \multicolumn{4}{|c|}{$\begin{array}{l}\text { Estimated discharge }\left(\mathrm{ft}^{3} / \mathrm{s}\right) \\
\text { by annual exceedance probability }\end{array}$} \\
\hline & 10 percent & 2 percent & 1 percent & 0.2 percent \\
\hline USGS SIR 2014-5084 (Wall and others, 2014), weighted log-Pearson type III & 35,400 & 58,600 & 69,600 & 99,100 \\
\hline
\end{tabular}




\section{Hydrologic Data}

The study reach includes one streamgage (station number 01350000 ; fig. 1; table 1) that has been in operation since November 1902. Stage is measured every 15 minutes, transmitted hourly by a satellite radio in the streamgage, and made available through the USGS National Water Information System (NWIS; U.S. Geological Survey, 2015c). Stage data from this streamgage are referenced to a local datum but can be converted to water-surface elevations referenced to the North American Vertical Datum of 1988 (NAVD 88) by adding 1,130.96 ft. Continuous records of streamflow are computed from a stage-discharge relation, which has been developed for the streamgage, and are available from the USGS NWIS (U.S. Geological Survey, 2015a).

The peak flows used in the model simulations (table 3) were taken from the current stage-discharge relation (rating number 82.0, effective August 28, 2011) and corresponded with the target stages. Two minor tributaries-Huntersfield Creek (drainage area $7.9 \mathrm{mi}^{2}$ ) and Johnson Hollow Brook (drainage area $5.2 \mathrm{mi}^{2}$ ) - join the Schoharie Creek in the Prattsville area; together they represent approximately
5 percent of the total contributing area at the downstream end of the modeled study reach. Huntersfield Creek joins Schoharie Creek roughly midway through the study reach, and Johnson Hollow Brook joins Schoharie Creek near the downstream end of the mapped study reach (fig. 1). The streamgage-derived discharges were modified, as necessary, to account for tributary inflows (table 3 ) by applying a drainagearea-ratio adjustment to the main-channel flows. Uncertainty due to variability of tributary inflow from the applied drainage-area-ratio adjustments was assessed by using a rough sensitivity analysis and is discussed in the "Uncertainties and Limitations Regarding Use of Flood-Inundation Maps" section.

\section{Topographic and Bathymetric Data}

All topographic data used in this study are referenced vertically to NAVD 88 and horizontally to the North American Datum of 1983. Cross-section elevation data were obtained from a DEM that was derived from lidar data that were collected and postprocessed during 2009 by Sanborn Map Company, Inc. The original lidar data have a horizontal

Table 3. Estimated discharges for corresponding stages and water-surface elevations at selected locations, used in the hydraulic model of the Schoharie Creek at Prattsville, New York.

[Map sheet number corresponds to flood-inundation map (http://dx.doi.org/10.3133/sir20155190). ft, feet; NAVD 88, North American Vertical Datum of $1988 ; \mathrm{ft}^{3} / \mathrm{s}$, cubic feet per second]

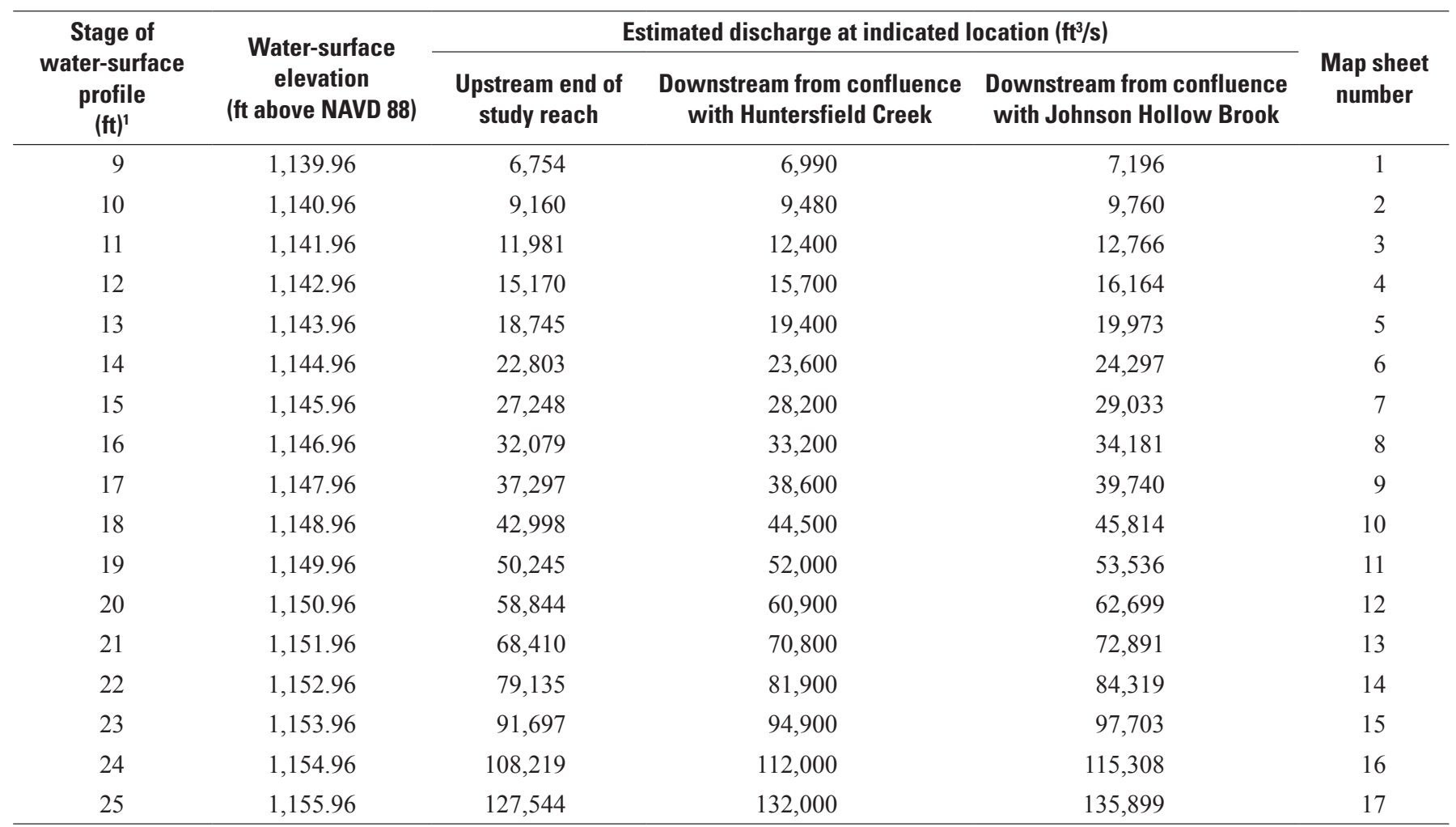

${ }^{1}$ Water-surface profiles are estimated for 1-foot increments of stage, referenced to the gage datum of the U.S. Geological Survey streamgage on Schoharie Creek at Prattsville, New York (station number 01350000). 
resolution of $6.6 \mathrm{ft}$ ( 2 meters) and a vertical root-mean squared error of $0.61 \mathrm{ft}$ ( 0.185 meters) for the open terrain land-cover category. These lidar meet the criteria to support production of $2-\mathrm{ft}$ contours (Dewberry, 2012). By using HEC-GeoRAS, a set of procedures, tools, and utilities for processing geospatial data in ArcGIS, elevation data were extracted from the DEM for 58 cross sections and subsequently were input to the HEC-RAS model. Because lidar data cannot provide ground elevations below a stream's water surface, channel cross sections were surveyed by USGS field crews during September and October of 2014; additional channel crosssection points near the State Route 23 bridge collected by the New York State Department of Transportation in April and June of 2014 were also incorporated in cross sections. Crosssectional depths were measured at 37 locations by wading or by using hydroacoustic instrumentation. A differential Global Positioning System with real-time kinematic (RTK) technology was used to derive horizontal locations and the elevation of the water surface at each surveyed cross section. Depths at sections too deep to wade were collected by using the vertical beam of a Sontek M9 acoustic Doppler current profiler (acoustic frequency of vertical beam 0.5 megahertz; firmware version 3.00; software version 3.7) equipped with an RTK Global Positioning System (GPS).

The DEM-generated cross sections were made to coincide with the locations of the within-channel, fieldsurveyed cross sections where possible. In these cases, withinchannel data were directly merged with the DEM data. For all other cross sections, the within-channel data were estimated by interpolation from the closest field-surveyed cross section.

\section{Hydraulic Structures}

One road crossing (State Route 23) and two low-head dams have the potential to affect water-surface elevations during floods along the stream. Bridge geometry data were obtained from field surveys by USGS personnel in 2014. The two fixed concrete low-head dams were included in the hydraulic model, both of which were surveyed by USGS personnel in 2014: one is south (upstream) of the Prattsville business district, and the other is at the downstream end of the study reach where Schoharie Creek enters Schoharie Reservoir.

\section{Energy-Loss Factors}

Hydraulic analyses require the estimation of energy losses that result from frictional resistance exerted by a channel on flow. These energy losses are quantified by the Manning's roughness coefficient ( $n$ value); $n$ values were selected on the basis of field observations and high-resolution aerial photographs. Main-channel $n$ values were assigned on the basis of observed substrate groups (such as fine sediment, gravel, cobbles, or boulders) to represent the wide, highgradient main channel. Overbank-channel $n$ values were assigned on the basis of land cover to represent the variably developed flood plain, which includes open fields, shrubs and forested sections, and moderately developed residential and commercial areas.

As part of the process of calibrating the hydraulic model, the initial $n$ values were varied by flow and adjusted until the differences between simulated and observed water-surface elevations at the streamgage were minimized over the range of mapped streamflows and at locations along the study reach where high-water-mark elevations from the August 28, 2011, flood were surveyed (see next section for more information). Roughness-coefficient adjustment factors were used in HECRAS to adjust $n$ values with flow. The roughness coefficients were lowest at the lowest flows (less than 50,000 cubic feet per second $\left[\mathrm{ft}^{3} / \mathrm{s}\right]$ ) and highest flows (greater than $100,000 \mathrm{ft}^{3} / \mathrm{s}$ ) modeled and were highest at moderately high flows $\left(75,000 \mathrm{ft}^{3} / \mathrm{s}\right)$. This pattern in $n$ values likely reflects the presence of vegetation, especially low brush, in the overbank areas immediately adjacent to the stream. As depth increases in the overbank areas and this vegetation is increasingly submerged, the roughness-coefficient adjustment factors (and effective $n$ values) decrease. Adjusted final $n$ values therefore ranged from 0.028 to 0.052 for the main channel and 0.043 to 0.063 for the overbank areas.

\section{Hydraulic Model}

The HEC-RAS analysis for this study was done by using the steady-state flow computation option. Steady-state flow data consisted of flow regime, boundary conditions, and peak flows that produced water-surface elevations at the streamgage cross section that matched target water-surface elevations. These target elevations coincided with even 1-ft increments of stage, referenced to the local streamgage datum. Subcritical (tranquil) flow regime was assumed for the simulations. Initial model runs, using a downstream boundary condition based on computed normal depth for an average water-surface slope of 0.003 , computed unstable water-surface profiles. Because of this result, and because water-surface elevations in the Schoharie Reservoir can vary by more than 50 feet within a single year, a synthetic stage-discharge rating curve was used as the modeled reach's downstream boundary condition. This rating curve was developed by using the initial model runs and the maximum reservoir level observed during the flood of August 2011. Water levels in Schoharie Reservoir can affect water levels upstream in Schoharie Creek, and a 0.9-mi reach of the hydraulic model was not mapped for this reason. Under most conditions investigated (reservoir levels up to $5 \mathrm{ft}$ higher than normal conditions), changes in reservoir levels do not create noticeable increases or decreases in inundated areas above the State Route 23 bridge and typically create only minor changes to inundated areas mapped below the bridge. Uncertainty due to variability of water levels in Schoharie Reservoir was assessed by using a rough sensitivity analysis and is discussed briefly in the "Uncertainties and Limitations Regarding Use of Flood-Inundation Maps" section. The 
flows used in the model are discussed in the "Hydrologic Data" section.

The HEC-RAS model was calibrated to the stagedischarge rating (number 82.0) at the Schoharie Creek streamgage and to documented high-water marks from the floods of August 28, 2011. The model was calibrated by adjusting Manning's $n$ values until the results of the hydraulic computations closely agreed with the expected water-surface elevations for given flows. Differences between observed and simulated water-surface elevations for the 17 simulated flows at the USGS streamgage were equal to or less than $0.34 \mathrm{ft}$ (table 4). Differences between observed high-water marks and simulated water-surface elevations in the study reach for the flood of August 28, 2011, were less than $1.1 \mathrm{ft}$, averaged about $0.1 \mathrm{ft}$, and had a median absolute deviation of $0.3 \mathrm{ft}$ (fig. 2). The results demonstrate that the model is capable of simulating accurate water levels over a wide range of flows in the basin.

Table 4. Calibration of model to observed water-surface elevations at U.S. Geological Survey streamgage on Schoharie Creek at Prattsville, New York (station number 01350000).

[ft, feet; NAVD 88, North American Vertical Datum of 1988]

\begin{tabular}{cccc}
\hline $\begin{array}{c}\text { Stage of } \\
\text { water-surface } \\
\text { profile } \\
\text { (ft) }\end{array}$ & $\begin{array}{c}\text { Target } \\
\text { water-surface } \\
\text { elevation } \\
\text { (ft above } \\
\text { NAVD 88) }\end{array}$ & $\begin{array}{c}\text { Modeled } \\
\text { water-surface } \\
\text { elevation } \\
\text { (ft above } \\
\text { NAVD 88) }\end{array}$ & $\begin{array}{c}\text { Difference } \\
\text { in elevation } \\
\text { (ft) }\end{array}$ \\
\hline 9 & $1,139.96$ & $1,140.04$ & 0.08 \\
10 & $1,140.96$ & $1,141.10$ & 0.14 \\
11 & $1,141.96$ & $1,142.16$ & 0.20 \\
12 & $1,142.96$ & $1,143.18$ & 0.22 \\
13 & $1,143.96$ & $1,144.20$ & 0.24 \\
14 & $1,144.96$ & $1,145.18$ & 0.22 \\
15 & $1,145.96$ & $1,146.15$ & 0.19 \\
16 & $1,146.96$ & $1,146.80$ & -0.16 \\
17 & $1,147.96$ & $1,147.71$ & -0.25 \\
18 & $1,148.96$ & $1,148.95$ & -0.01 \\
19 & $1,149.96$ & $1,149.82$ & -0.14 \\
20 & $1,150.96$ & $1,150.74$ & -0.22 \\
21 & $1,151.96$ & $1,151.69$ & -0.27 \\
22 & $1,152.96$ & $1,152.89$ & -0.07 \\
23 & $1,153.96$ & $1,153.97$ & 0.01 \\
24 & $1,154.96$ & $1,155.05$ & 0.09 \\
25 & $1,155.96$ & $1,156.30$ & 0.34 \\
\hline
\end{tabular}

\section{Development of Water-Surface Profiles}

The calibrated hydraulic model was used to generate water-surface profiles for 17 stages at 1 -ft intervals between $9 \mathrm{ft}$ and $25 \mathrm{ft}$, referenced to the local datum of the Schoharie Creek at Prattsville streamgage. The stages of $9 \mathrm{ft}$ and $25 \mathrm{ft}$ correspond to elevations of $1,139.96 \mathrm{ft}$ and $1,155.96 \mathrm{ft}$ (referenced to NAVD 88), respectively. Discharges corresponding to the various stages were obtained from the stage-discharge rating (number 82.0) for the Schoharie Creek at Prattsville streamgage (station 01350000). Discharges through the study reach were adjusted, as necessary, for tributary inflows shown in table 3.

\section{Development of Flood-Inundation Maps}

Flood-inundation maps were created in a GIS for the 17 water-surface profiles by combining the profiles and DEM data. The DEM data were derived from the lidar data described previously in the "Topographic and Bathymetric Data" section and therefore have an estimated vertical accuracy of $2 \mathrm{ft}$ (that is, plus or minus $1 \mathrm{ft}$ ). Estimated flood-inundation boundaries for each simulated profile were developed with the HEC-GeoRAS software (U.S. Army Corps of Engineers, Hydrologic Engineering Center, 2009), which allows the preparation of geometric data for import into HEC-RAS and processes simulation results exported from HEC-RAS (U.S. Army Corps of Engineers, Hydrologic Engineering Center, 2010). Shapefile polygons and depth grids of the inundated areas for each profile were modified, as required, in the ArcMap application of ArcGIS (Esri, Inc., 2015) to ensure a hydraulically reasonable transition of the flood boundaries between modeled cross sections.

Any inundated areas that were detached from the main channel were examined to identify subsurface connections with the main river, such as through culverts under roadways. Where such connections existed, the mapped inundated areas were retained in their respective flood maps; otherwise, the erroneously delineated parts of the flood extent were deleted. The flood-inundation areas are overlaid on high-resolution, georeferenced, aerial photographs of the study area. The State Route 23 bridge surface is shown as noninundated up to the lowest flood stage that intersects the lowest structural chord of the bridge; at and above this stage $(22 \mathrm{ft})$, the bridge surface is depicted as being inundated. Estimates of water depth can be obtained from the depth-grid data that are included with the presentation of the flood maps on an interactive USGS mapping application described in the "Flood-Inundation Map Delivery" section. The flood map corresponding to the highest simulated water-surface profile, a stage of $25 \mathrm{ft}$, is presented in figure 3. 


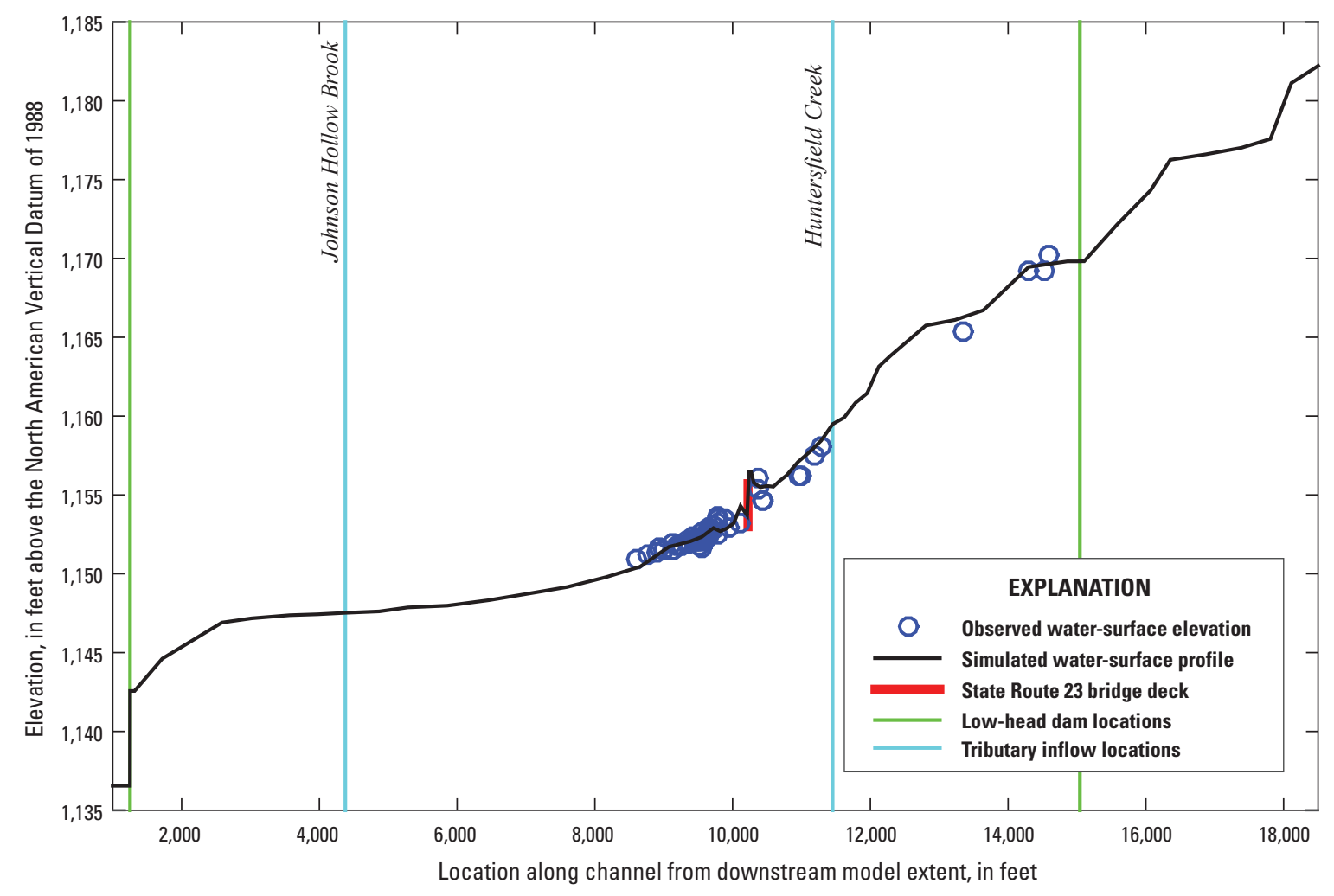

Figure 2. Observed water-surface elevations and simulated water-surface profile for the flood of August 28, 2011, for Schoharie Creek at Prattsville, New York.

\section{Flood-Inundation Map Delivery}

The current study documentation is available online at the USGS Publications Warehouse (http://dx.doi.org/10.3133/ sir20155190). Also, a Flood Inundation Mapping Science Web site (http://water.usgs.gov/osw/flood_inundation; U.S. Geological Survey, 2015b) makes USGS flood-inundation study information available to the public. A link to a mapping application that presents map libraries and provides detailed information on flood extents and depths for modeled sites is available on the USGS Flood Inundation Mapping Program Web site. The mapping application enables the production of customized flood-inundation maps from the map library for Schoharie Creek at Prattsville.

A link on this Web site connects to the USGS National Water Information System (U.S. Geological Survey, 2015a), which presents the current stage and streamflow at the USGS streamgage 01350000 , to which the inundation maps are referenced. Another link connects to the NWS Advanced Hydrologic Prediction Service (AHPS) site (National Weather Service, 2015b) so that the user can obtain applicable information on forecasted peak stage. The maps of estimated flood-inundation are displayed in sufficient detail so that preparations for flooding and decisions for emergency response can be efficient. Depending on the flood magnitude, roadways are shown as shaded (inundated and likely impassable) or not shaded (dry and passable) to facilitate emergency planning and use. Bridges are shadedthat is, shown as inundated - if the flood profile intersects the lowest structural chord of the bridge. A shaded building should not be interpreted to mean that the structure is completely submerged; rather, it means that bare Earth surfaces in the vicinity of the building are inundated. In these instances, the water depth (as indicated in the mapping application by holding the cursor over an inundated area) near the building would be an estimate of the water level inside the structure, unless flood-proofing measures had been implemented.

\section{Disclaimer for Flood-Inundation Maps}

Inundated areas shown should not be used for navigation, regulatory, permitting, or other legal purposes. The USGS provides these maps "as-is" for a quick reference, emergency planning tool but assumes no legal liability or responsibility resulting from the use of this information. 


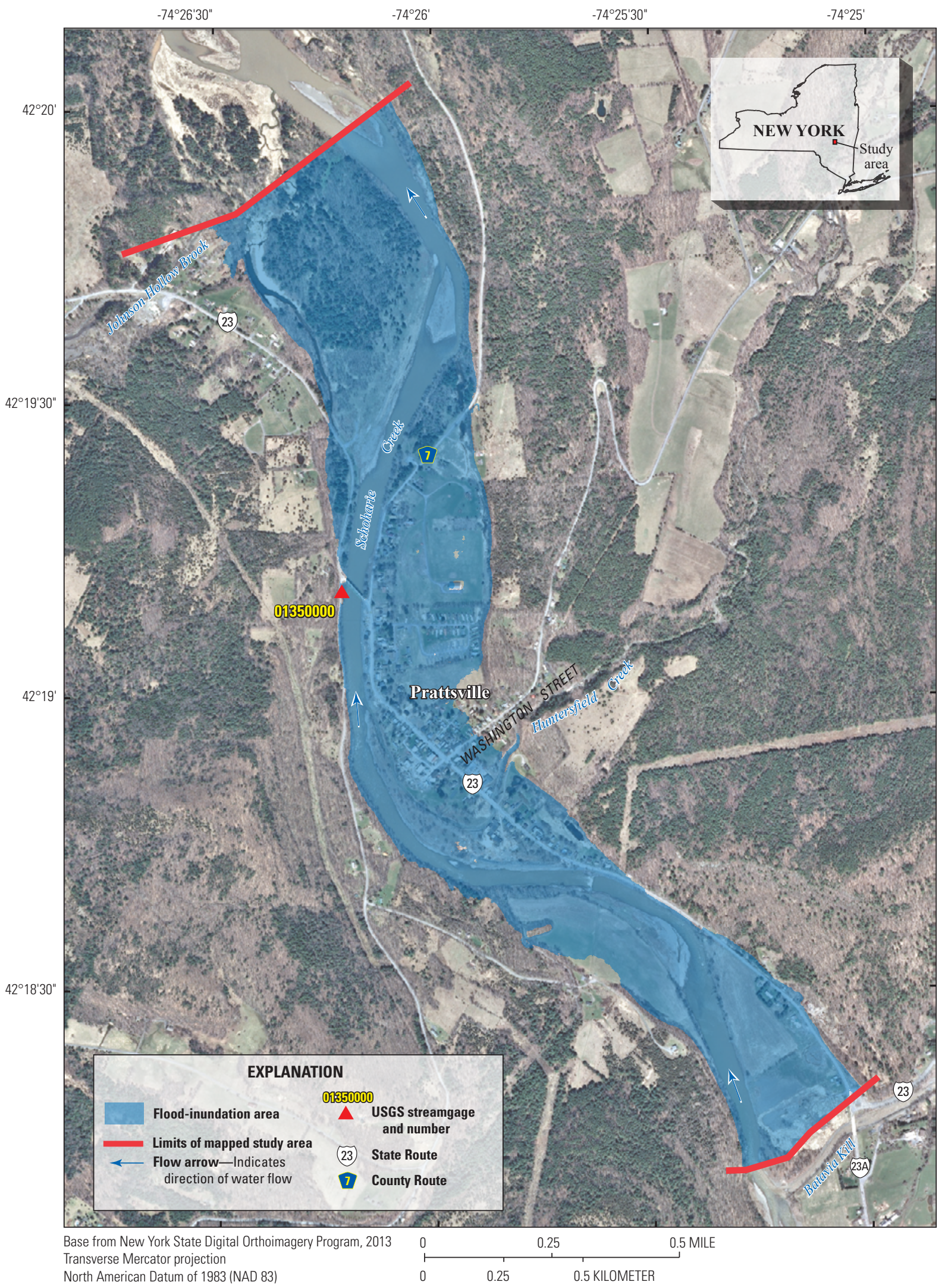

Figure 3. Flood-inundation map for the Schoharie Creek at Prattsville, New York, corresponding to a stage of 25.00 feet at the U.S. Geological Survey (USGS) streamgage (station number 01350000). 


\section{Uncertainties and Limitations Regarding Use of Flood-Inundation Maps}

Although the flood-inundation maps represent the boundaries of inundated areas with a distinct line, some uncertainty is associated with these maps. The flood boundaries shown were estimated on the basis of water stages and streamflows at the Schoharie Creek at Prattsville streamgage. Water-surface elevations along the stream reach were estimated by steady-state hydraulic modeling, assuming unobstructed flow, and using streamflows and hydrologic conditions anticipated at the USGS streamgage. The hydraulic model reflects the land-cover characteristics and any bridge, dam, levee, or other hydraulic structures existing as of October 2014. Unique meteorological factors (timing and distribution of precipitation) may cause actual flood streamflows along the modeled reach to vary from those assumed, which may lead to deviations from the water-surface elevations and inundation boundaries shown. Seasonal growth of vegetation in overbank areas, especially of low brush such as the Japanese knotweed present in many locations along the study reach, may alter effective energy-loss factors ( $n$ values) and thereby inundation areas. Additional areas may be flooded because of unanticipated conditions such as changes in the streambed elevation or roughness, backwater into or from major tributaries along a main stem river, or backwater from localized debris or ice jams. The accuracy of the floodwater extent portrayed on these maps will vary with the accuracy of the DEM used to simulate the land surface.

A planned (as of 2015) replacement of the State Route 23 bridge will likely alter the hydraulic properties of the stream channel as well as the stage-discharge relation at the streamgage. Therefore, revisions of the hydraulic model and mapped inundation areas will likely be required.

The streamflow contributed to the Schoharie Creek by its tributaries was modeled by using drainage-area ratios. During flood events, inflows from tributaries can deviate from the calculated values because of differences in precipitation over time and space, differences in travel times of runoff within a basin, differences in the forms of the typical hydrograph for each basin, and regulation of flow, among many other potential causes. To assess the potential effect on the mapped inundation areas, the 17 water-surface profiles were modeled under six additional scenarios, in which the streamflow contributed from Huntersfield Creek, the largest tributary in the study reach, was modeled as 0.5-, 0.8-, 0.9-, 1.1-, 1.2-, and 1.5-times the original tributary streamflow calculated by using drainage-area ratios. Results showed that the largest effects were typically in areas just downstream of Huntersfield Creek; the largest increase in water-surface elevation was $0.9 \mathrm{ft}$ in one model cross section, which was for the 1.5-times flow scenario for the highest modeled profile. More than half of the profiles did not have water-surface-elevation increases greater than $0.3 \mathrm{ft}$ for the 1.5 -times flow scenario. For the 0.5 -times flow scenario, the largest decrease in water-surface elevation was approximately $0.4 \mathrm{ft}$ in one model cross section, and more than half of the profiles did not have water-surface-elevation decreases greater than $0.3 \mathrm{ft}$. Effects were generally smaller for the 0.8-, 0.9-, 1.1-, and 1.2-times flow scenarios. For all combinations of flow scenarios and profiles, some effect of the change in flow from Huntersfield Creek did propagate downstream through the study reach; in most of the model cross sections, the effect was less than $0.1 \mathrm{ft}$. The effect of the modified tributary inflow was small through most of the mapped study reach, and deviation of the tributary inflow from the calculated values is likely to depend on an individual storm event. Consequently, the initial tributary inflows calculated from drainage-area ratios were used to generate the watersurface profiles that were used to create the flood-inundation maps. However, the user should be aware that additional areas may be inundated because of flooding in and along the tributaries to Schoharie Creek rather than from flooding of Schoharie Creek itself.

Water-surface elevations in the study reach can also be affected by the level of the Schoharie Reservoir. To limit this effect, the mapped study reach was clipped approximately $0.5 \mathrm{mi}$ upstream of the reservoir. However, to assess the potential effect of the level of the reservoir on the mapped inundation areas, the 17 water-surface profiles were modeled under six additional scenarios, in which the water-surface elevation at the downstream boundary of the model was varied from $5 \mathrm{ft}$ below to $5 \mathrm{ft}$ above the original model value $(-5,-2,-1,+1+2$, and $+5 \mathrm{ft})$. As might be expected, the largest effects of the change in downstream boundary condition were at the downstream end of the mapped reach, nearest the reservoir. For the scenarios of $-5,-2,-1$, and $+1 \mathrm{ft}$, modeled water-surface elevations did not change more than $0.5 \mathrm{ft}$ in any location in the mapped reach. For the scenario of $+2 \mathrm{ft}$, the maximum water-surface-elevation change in the mapped reach was less than $0.9 \mathrm{ft}$, and changes greater than $0.5 \mathrm{ft}$ were only observed in profiles in the furthest downstream 2,000 ft of the mapped reach. The largest effects occurred in the scenario of $+5 \mathrm{ft}$, in which the furthest downstream cross sections in the mapped reach changed by approximately $2.9 \mathrm{ft}$ for moderately high flows, but changes greater than $1 \mathrm{ft}$ only occurred in the furthest downstream 3,500 ft of the mapped reach and did not occur in any location for the three highest modeled flows. The effect of the change in downstream boundary conditions extended furthest upstream in the moderately high flow profiles. None of the scenarios caused more than $0.1 \mathrm{ft}$ change in water-surface elevations in any location that was more than $0.8 \mathrm{mi}$ upstream from the downstream limit of the mapped reach (about 1,000 ft downstream from the State Route 23 bridge). Because the effect of the modified water levels at the downstream boundary of the model was small through most of the mapped study reach, the initial water-surface elevations at the downstream boundary of the model were used, and the mapped inundation areas should be reasonably well represented by these model conditions.

If this series of flood-inundation maps will be used in conjunction with NWS river forecasts, the user should be aware of additional uncertainties that may be inherent 
or factored into NWS forecast procedures. The NWS uses forecast models to estimate the quantity and timing of water flowing through selected stream reaches in the United States. These forecast models (1) estimate the amount of runoff generated by precipitation and snowmelt, (2) simulate the movement of floodwater as it proceeds downstream, and (3) predict the flow and stage (and water-surface elevation) for the stream at a given location (AHPS forecast point; National Weather Service, n.d.) throughout the forecast period (every 6 hours for 3 to 5 days before a flood in many locations).

\section{Summary}

A series of 17 digital flood-inundation maps was developed, in cooperation with the New York State Department of Environmental Conservation, for the Schoharie Creek at Prattsville, New York. The maps cover a reach about 2.6 miles long, from the confluence with the Batavia Kill to 0.5 mile upstream of Schoharie Reservoir. The maps were developed by using the U.S. Army Corps of Engineers Hydrologic Engineering Center River Analysis System (HECRAS) and HEC-GeoRAS programs to compute water-surface profiles and to delineate estimated flood-inundation areas and depths of flooding for selected stream stages. The HEC-RAS hydraulic model was calibrated to the stage-discharge relation (rating 82.0) at the Schoharie Creek streamgage and to highwater marks observed after the August 28, 2011, flood. The model was used to compute 17 water-surface profiles for flood stages at 1 -foot intervals referenced to the streamgage datum and ranging from 9 feet, or near bankfull, to 25 feet, which exceeds the stage of the maximum recorded peak flow. The simulated water-surface profiles were then combined with a geographic information system digital elevation model derived from light detection and ranging (lidar) data to delineate estimated flood-inundation areas as shapefile polygons and depth grids for each profile. These flood-inundation polygons were overlaid on high-resolution, georeferenced aerial photographs of the study area. The flood maps are available through a mapping application that can be accessed on the U.S. Geological Survey Flood Inundation Mapping Science Web site (http://water.usgs.gov/osw/flood_inundation).

Flood-inundation maps for Schoharie Creek at Prattsville, in conjunction with the real-time stage data from the USGS streamgage at Schoharie Creek at Prattsville (station number 01350000) and forecasted flood stage data from the National Weather Service Advanced Hydrologic Prediction Service, can help guide the general public in taking individual safety precautions and can provide emergency management personnel with a tool to efficiently manage emergency flood operations and postflood recovery efforts.

\section{References Cited}

Dewberry, 2012, National enhanced elevation assessment: Fairfax, Va., Dewberry, 84 p., accessed July 9, 2013, at http://www.dewberry.com/docs/default-source/documents/ neea_final-report_revised-3-29-12.pdf?sfvrsn $=0$.

Esri, Inc., 2015, ArcGIS: Esri, Inc., Web site, accessed March 24, 2015, at http://www.esri.com/software/arcgis/.

Federal Emergency Management Agency, 2008, Flood insurance study, Greene County, New York: Federal Emergency Management Agency, 54 p., 136 pls.

Homer, C.G., Dewitz, J.A., Yang, Limin, Jin, Suming, Danielson, Patrick, Xian, George, Coulston, John, Herold, N.D., Wickham, J.D., and Megown, Kevin, 2015, Completion of the 2011 national land cover database for the conterminous United States - Representing a decade of land cover change information: Photogrammetric Engineering and Remote Sensing, v. 81, no. 5, p. 345-354.

Lumia, Richard, 1998, Flood of January 19-20, 1996, in New York State: U.S. Geological Survey Water-Resources Investigations Report 97-4252, 61 p. [Also available at http://pubs.er.usgs.gov/publication/wri974252.]

Lumia, Richard, Firda, G.D., and Smith, T.L., 2014, Floods of 2011 in New York: U.S. Geological Survey Scientific Investigations Report 2014-5058, 236 p. [Also available at http://dx.doi.org/10.3133/sir20145058.]

Milone and MacBroom, Inc., 2013, Final draft local flood hazard mitigation analysis - Schoharie Creek watershed, town of Prattsville, Greene County, New York: Cheshire, Conn., Milone and MacBroom, Inc., [variously paged], accessed October 27, 2014, at http://catskillstreams.org/ wp-content/uploads/2015/01/LFA_Prattsville.pdf.

National Weather Service, 2015a, Action stage: National Weather Service glossary Web page, accessed March 24, 2015, at http://w1.weather.gov/glossary/index. php? word=action + stage.

National Weather Service, 2015b, Schoharie Creek at Prattsville: National Weather Service Advanced Hydrologic Prediction Service data, accessed March 24, 2015, at http://water.weather.gov/ahps2/ hydrograph.php?wfo=aly\&gage=PTVN6.

National Weather Service, [n.d.], A brief overview of the NWS precipitation and river forecasting and the river forecast on the APHS hydrograph: National Weather Service, 1 p., accessed November 18, 2015, at http://water.weather.gov/ ahps/pcpn_and_river_forecasting.pdf. 
NY Rising Community Reconstruction Program Prattsville Planning Committee, 2014, NYRCR Prattsville-NY rising community reconstruction plan: New York, NY Rising Community Reconstruction Program, [variously paged], accessed February 9, 2015, at https://stormrecovery.ny.gov/ sites/default/files/crp/community/documents/prattsville nyrer_plan.pdf.

New York State Department of Transportation, 2014, Governor Andrew M. Cuomo's scour critical/flood prone bridge program: New York State Department of Transportation Web page, accessed July 23, 2015, at https://www.dot.ny.gov/cbow.

U.S. Army Corps of Engineers, Hydrologic Engineering Center, 2009, HEC-GeoRAS - GIS tools for support of HEC-RAS using ArcGIS, user's manual (ver. 4.2): U.S. Army Corps of Engineers CPD-83, [variously paged].

U.S. Army Corps of Engineers, Hydrologic Engineering Center, 2010, HEC-RAS river analysis system, hydraulic reference manual (ver. 4.1): U.S. Army Corps of Engineers CPD-69, [variously paged].

U.S. Census Bureau, 2010, American FactFinder: U.S. Census Bureau database, accessed March 24, 2015, at http://factfinder2.census.gov/.
U.S. Geological Survey, 2015a, USGS 01350000 Schoharie Creek at Prattsville, NY: U.S. Geological Survey National Water Information System Web page, accessed March 24, 2015, at http://waterdata.usgs.gov/ny/nwis/ uv?site_no $=01350000$.

U.S. Geological Survey, 2015b, USGS flood inundation mapping science: U.S. Geological Survey Web site, accessed March 24, 2015, at http://water.usgs.gov/osw/ flood_inundation.

U.S. Geological Survey, 2015c, USGS surface-water data for the Nation: U.S. Geological Survey National Water Information System, accessed March 24, 2015, at http://waterdata.usgs.gov/nwis/sw.

Wall, G.R., Murray, P.M., Lumia, Richard, and Suro, T.P., 2014, Maximum known stages and discharges of New York streams and their annual exceedance probabilities through September 2011: U.S. Geological Survey Scientific Investigations Report 2014-5084, 16 p., accessed December 23, 2014, at http://dx.doi.org/10.3133/ $\operatorname{sir} 20145084$.

Zembrzuski, T.J., and Evans, M.L., 1989, Flood of April 4-5, 1987, in southeastern New York state, with flood profiles of Schoharie Creek: U.S. Geological Survey Water-Resources Investigations Report 89-4084, 41 p. [Also available at http://pubs.er.usgs.gov/publication/wri894084.] 
For additional information write to: Director, New York Water Science Center U.S. Geological Survey

425 Jordan Road

Troy, NY 12180-8349

Email: dc_ny@usgs.gov

Information requests:

(518) 285-5602

or visit our Web site at: http://ny.water.usgs.gov

Publishing support by:

The Pembroke Publishing Service Center. 


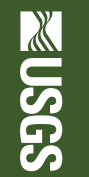

